\title{
Opportunities for German Companies in the Onshore Wind Power Market of the Russian Federation
}

\author{
Andreas BECKER and Guan-wei HUANG*
}

Sino-German School for Postgraduate Studies, Tongji University, Shanghai, China.

*Corresponding author

Keywords: Wind Power, Market Opportunities, Russia, Germany, Market Entry.

\begin{abstract}
This paper intends to analyze the opportunities for German companies in the onshore wind power market of the Russian Federation. The model will consist of the following methods: Pestel Analysis, Porter's Five Forces and the SWOT Analysis. Each method has its advantages and disadvantages, yet in combination, they create an approximate holistic and elaborated assessment of the market situation and the company's opportunities. The external market environment will be analyzed with the Pestel Analysis and the external industry environment with Five Forces Analysis. The internal strengths and weaknesses of a company will be analyzed with the SWOT Analysis. As an example, some potential companies entering the market are going to be mentioned.
\end{abstract}

\section{Introduction}

The production of wind power has developed enormously over the last decades. Reasons for the strong development were the need for the reduction of greenhouse gas emissions, the reduction of the dependence on energy imports but also economic growth. In 2016, $54 \mathrm{GW}$ of wind power have been installed worldwide and the total installed wind power capacity has reached $486 \mathrm{GW}$. The leading countries in that development are the USA, Germany, India, Spain and China [1]. In comparison, Russia is among the countries with the highest emissions world wide and clearly dragging behind in this development. Russia has an enormous potential for the development of wind energy but will need the technologies and expertise of international companies from countries like Germany to develop its wind energy industry. At the same time, the Russian market can become a new and profitable market for wind power and an opportunity for German companies to grow and expand in the near future.

\section{Theoretical Background}

Wind energy does not have an important role in the Russian energy mix. The installed capacity is less than $1 \%$ of the total electricity production [2]. There are currently ten wind farms in the MW scale operating in Russia with a total capacity of about $17 \mathrm{MW}$. Most projects are located in the south of Russia's European part although some parts in this areas have less favorable wind conditions but a high population density and a well developed transmission grid. Russia has the world's biggest wind resources and could also become Europe's largest producer and exporter of wind energy $[3,4]$. The German wind industry, on the other hand, is very well developed and had a good performance in recent years [5]. The development of renewable energy has many advantages as it can foster economic growth, diversify the energy mix, improve energy security, reduce costs of energy supply to remote regions and help to achieve international commitments as the Paris Agreement [4,6].

\section{Methods}

The analysis of the Russian wind power market and the chances for German companies follows the pattern displayed in Figure 1. The model consists of the following methods: Pestel Analysis, Porter's Five Forces and the SWOT Analysis. These methods have proven to be effective in the analysis of a company's surrounding and business opportunities and are widely used in academic 
literature. Pestel is an abbreviation for: Political, Economical, Social, Technological, Environmental and Legal. The framework is going to analyze each factor of the external macro-environment and how they are influencing the business of the company $[7,8]$.

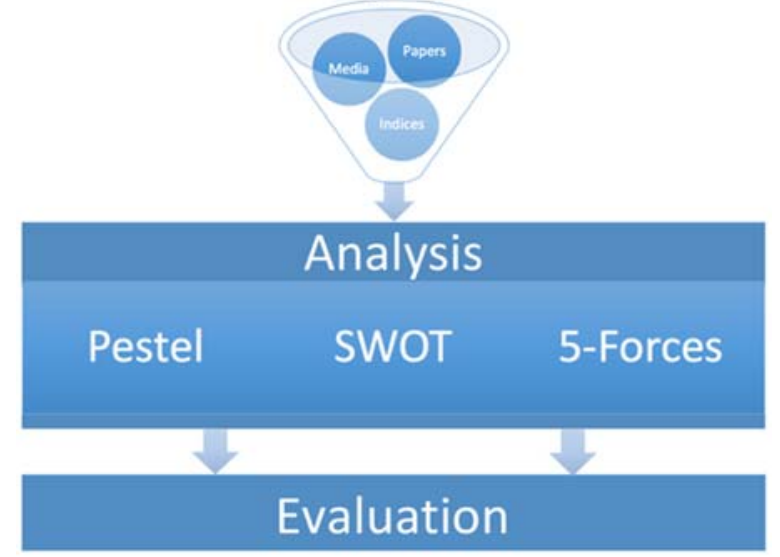

Figure 1. Methodological approach (Own representation)

The Five Forces Analysis helps a company to evaluate the potential profitability within the industry and also its own competitive position. These five forces are: the rivalry among existing competitors, the threat of new entrants, the threat of substitute products and the bargaining power of customers and suppliers. It is necessary to understand how these forces work in the industry and how they affect the company and its situation [9]. The SWOT Analysis examines the company's internal Strengths and Weaknesses as well as its external Opportunities and Threats. The company analyzes its strengths to match them with profitable opportunities and determine possible strategic actions while minimizing its internal weaknesses and avoiding external threats [7]. During this analysis, German companies will be compared with present or highly potential international competitors on the market according to certain factors like financial resources and economies of scale, in order to evaluate its relative competitive strength.

\section{Results of the Analysis}

The table below shows an overview of the results of the Pestel and Five Forces Analysis according to all covered factors. The current status and the development of the single factors are evaluated with symbols from '++' for very good, over 'o' for moderate and up to '- -' for very bad. Moreover, the importance of every factor is classified from very high to very low. This makes the descriptive and results easy to understand and enables a more specified differentiation without allowing to much subjectivity. The evaluation of the Five Forces is done from the perspective of German OEMs as some potential competitors that could enter the market in the future.

The Pestel Analysis shows that the Russian government finally shows interest in the development of wind energy. In former years, the political will has been rather low but the support mechanism for renewable energy sources has been improved and specified in order to assist domestic and foreign investors $[4,6,10]$. Still, there are general problems within the market like bureaucracy as it can retard processes and influence daily business and procedures can be time-consuming. Corruption and bribery are considered a convenient alternative to administrative compliance although the situation has already improved and the trend is positive [11].

The economic situation is steadily improving. After the GDP declined by $2.8 \%$ in 2015 , it is growing again since the end of 2016 and Russia is out of recession [12]. As a result of the economic crisis and the sanctions, German exports to Russia dropped significantly in 2015 but rather stabilized again in 2016 [13]. Concerning renewable energy, the awareness is rather weak. However, there is a trend for change as the media has started to report favorably about wind energy and the environmental year 2017 could help to spread awareness and knowledge about renewable energies [14]. In regard to social factors, business relationships are rather built on trust and personal relations than objective factors like price and quality [15]. There is a lack of local technologies expertise, but 
the development is quite positive as the "Skolkovo Research Foundation" provides financial support to various projects in the field of wind power [4]. Moreover, the country has many materials needed for the manufacturing of wind turbines such as iron, copper and aluminum [16].

Table 1. Evaluation of the Pestel and Five Forces Analysis (Own representation)

\begin{tabular}{|l|c|c|c|}
\hline \multicolumn{1}{|c|}{ Factor } & Status quo & Development & Importance \\
\hline Pestel Analysis & & & \\
\hline Political & + & ++ & Very high \\
\hline Economical & 0 & + & High \\
\hline Social & - & 0 & Medium \\
\hline Technological & 0 & + & High \\
\hline Legal & + & + & Very high \\
\hline Environmental & - & + & Medium \\
\hline Five Forces Analysis & + & - & High \\
\hline Existing competitors & + & - & High \\
\hline Threat of entry & 0 & + & Medium \\
\hline Threat of substitutes & - & + & Medium \\
\hline Power of supplier & + & - & Medium \\
\hline Power of buyers & 0 & & \\
\hline
\end{tabular}

Considering logistic issues, the transportation would take more time and be more expensive than in comparable projects in Europe. Regions like South Federal District, however, are easy to access by the main transportation lines and large rivers like the Volga, which connects many large cities in the European part [6,17].

The legislative environment has improved a lot in recent years and a capacity based support mechanism was introduced that guarantees payments for 15 years in order to ensure a sufficient return on investment. The government has introduced tender with a local content requirement for wind turbines and components that demands 55\% from 2018 and 65\% from 2019 [10]. As a result of the 2017 tender, a capacity of $1.65 \mathrm{GW}$ of wind power will be constructed and the OEMs supplying wind turbines and establishing local production in Russia will be Vestas, SiemensGamesa and the coorporation between Rosatom and Lagerwey [3].

The Five Forces Analysis has further revealed that the traditional energy sources are backed by a strong lobby and are dominating the interest of the government as they produce a large share of the GDP while wind energy is a new competitor on the country's electricity market. Nuclear power is the biggest threat to wind energy since the government plans to increase the capacity and promotes it as a clean and emission free technology [18]. One example for German wind turbine manufacturers is Enercon, the market leader in German and the 5th largest manufacturer world wide [19]. The profitable home market is also one of Enercon's weaknesses as the company dependents on it but the potential competitors Vestas and Siemens Gamesa are more active internationally. Due to their size and geographical distribution, they are less vulnerable to fluctuations in the market and can generate economies of scale to optimize their costs [20,21]. Enercon has a very high manufacturing penetration and is successful due to its technology leadership and very good service. The profit is invested in $R \& D$ and the independence from suppliers. The company has the required international experience as well as some resources and capacities.

The following table depicts the results of the SWOT Analysis. The global players Vestas and Siemens Gamesa represent serious competitors and will pose a credible threat to Enercon, once they have fully entered the Russian market. 
Table 2. SWOT Analysis for Enercon as an example for German OEMs (Own representation)

\begin{tabular}{|c|c|}
\hline Strengths & Weaknesses \\
\hline $\begin{array}{l}\text { - } \text { Strong home market } \\
\text { - } \text { Global player }\left(5^{\text {th }} \text { worldwide }\right) \\
\text { - } \text { Global production } \\
\text { - Strong brand } \\
\text { - High quality } \\
\text { - High experiences internationally } \\
\text { - } \text { Broad product portfolio } \\
\text { - } \text { Direct drive turbines } \\
\text { - Focus on technology and R\&D } \\
\text { - Very high manufacturing penetration }\end{array}$ & $\begin{array}{l}\text { - Expensive wind turbines } \\
\text { - Dependence on the German market } \\
\text { - No experience with the Russian market } \\
\text { - Fewer financial resources than competitors }\end{array}$ \\
\hline Opportunities & Threats \\
\hline $\begin{array}{l}\text { - Licensing-agreement } \\
\text { - Great technical and economic wind energy } \\
\text { potential } \\
\text { - Good technological basis } \\
\text { - Many raw materials }\end{array}$ & $\begin{array}{l}\text { - } \text { Strong competitors } \\
\text { - Traditional energy sources (nuclear power) } \\
\text { - Bureaucracy and corruption } \\
\text { - High entry barriers (local content) } \\
\text { - Low price of fossil resources } \\
\text { - } \quad \text { No supplier base for MW turbines }\end{array}$ \\
\hline
\end{tabular}

Especially, the company Siemens Gamesa with its product portfolio, strong financial resources, economies of scale and experience in Russian has a very good position and high chances of being successful [20,21]. The cooperation between Lagerwey and Rosatom has a less broad product portfolio but access to the network and the experience of Rosatom, as a state-owned company.

Table 3. Comparison of potential competitors on the Russian market (Own representation)

\begin{tabular}{|c|c|c|c|c|}
\hline Factor & Vestas & $\begin{array}{c}\text { Rosatom- } \\
\text { Lagerwey }\end{array}$ & $\begin{array}{c}\text { Siemens- } \\
\text { Gamesa. }\end{array}$ & Enercon \\
\hline Product portfolio & ++ & 0 & ++ & ++ \\
\hline Experience in Russia & 0 & ++ & ++ & - \\
\hline Int. experience & ++ & $/$ & ++ & + \\
\hline Financial resources & + & + & ++ & 0 \\
\hline
\end{tabular}

\section{Conclusion}

Despite manufacturing of wind turbines and components, German companies have generally good opportunities within project development, infrastructure and management as Russian companies lack expertise and experience in these areas. Due to the high quality of its wind turbines and the traditionally good image of its products in Russia, German companies would have an advantage. However, the current market size could be too small for several global player and it is difficult to anticipate the possible size after the end of the support program in 2024. For a cautious company like Enercon that avoids risky markets, it is not advisable to invest in the Russian market at the moment.

A German company could, monitor the development of the market and prepare to invest as soon as the situation becomes better or choose the active approach and establish a strong presence with local manufacturing in order to fight for market share. There would is also the opportunity of penetrating the markets of neighboring countries like Belarus and Kazakhstan. The industry is only beginning to develop and during the next years, the wind industry of the Russian Federation can grow enormously. German companies could benefit considerably by engaging in that development. 


\section{References}

[1] EBR (2017): Energy Business Review: Top wind turbine companies, URL: http://wind.energybusiness-review.com/news/top-wind-turbine-companies-5864985.

[2] IEA (2014): Russia 2014, International Energy Agency, OECD/IEA, Paris.

[3] ATS (2017): Конкурсный отбор проектов ВИЭ, Результаты отборов проектов, Results of the tender, Administrator of the Trading System, Moscow 2017.

[4] IRENA (2017): Remap 2030: Renewable energy prospects for the Russian Federation, Working paper, International Renewable Energy Agency.

[5] BWE (2017): Bundesverband WindEnergie e.V.: Onshore wind energy: Analysis of the German market in 2016 and outlook for 2017, Berlin 2017.

[6] Lighthouse (2013): Quick Scan of Wind, Solar Energy and Combined Heat and Power in the Russian Federation, Lighthouse Russia B.V. 2013.

[7] Kotler, Armstrong (2012): Principles of marketing, Global Edition, fourteenth edition, ISBN 10 : 0-273-75243-X, Pearson education limited 2012.

[8] Sieck (2014): Siemens wind power and the U.S. market for wind energy - An analysis of environmental factors impacting a turbine manufacturer, Universitas Arhusiensis.

[9] Porter, M. (2000): How competitive forces shape strategy, Harvard Business Review.

[10] Government of the Russian Federation: Decree No. 1472-r (2015), Moscow 2015.

[11] Swedish Trade Council (2016): Business Climate Survey Russia 2016, Stockholm 2016.

[12]Trading Economics (2017): Russia GDP Annual Growth Rate, URL: http://www.tradingeconomics.com/russia/gdp-growth-annual.

[13] German Federal Foreign Office (2017): Außen- und Europapolitik: Länderinformationen: Russische Föderation, Beziehungen zu Deutschland, Berlin 2017.

[14]Rossiya1 (2017): Начало строительства ветропарка под Ульяновском, Moscow 2017.

[15]Ledeneva (2013): Can Russia Modernize?, Sistema, Power Networks and Informal Governance, ISBN: 9780521125635 , Cambridge University Press, Cambridge 2013.

[16]CIA (2017): Library: The world factbook: Natural resources, URL: https://www.cia.gov/library/publications/the-world-factbook/fields/2111.html.

[17] Capgemini Consulting (2007): Logistics map of Russia 2007.

[18]Eliseeva, Borozdina (2012): Optimization of Energy Production under the View of Technical, Economic and Environmental Conditions, Technische Universität Berlin, Germany.

[19]Enercon (2017b): Marktanteil, URL: http://www.enercon.de/unternehmen/marktanteile/.

[20] Gamesa (2017): Gamesa 2016: 2016 Annual Report, Direccion de Comunication, Madrid.

[21] Siemens (2017): Siemens AG: Annual report 2016, Berlin and Munich 2016. 